\title{
Animal Release and the Sacrificial Ethos in Inner Asia
}

\author{
Katherine Swancutt \\ Senior Lecturer in the Anthropology of Religion and Director of the \\ Religious and Ethnic Diversity in China and Asia Research Unit, \\ Department of Theology and Religious Studies, King's College London, \\ London, UK \\ katherine.swancutt@kcl.ac.uk
}

\begin{abstract}
Animal release is often understood as the practice of freeing an animal from human consumption or the burden of labour. Typically associated with various Buddhist or Daoist cosmologies in which liberating an animal is a merit-making act, animal release tends to be conceptualised in altruistic terms. Yet the diverse forms that sacrifice and animal release take across Inner Asia suggest that the focus of analysis sometimes shifts from a concern with freeing animals to protecting the human imperative to live. Introducing new ethnography on the ethical underpinnings of sacrifice among Buryats in northeast Mongolia and the Nuosu of southwest China, I propose that animal release can be an act of restrained violence that evokes the mythopoetic contours of human-animal relations, animal sentience and human self-preservation. Offering case studies on scapegoats, deferred sacrifice, and contingent forms of slaughter, I show how Buryats and Nuosu manage the ethical tensions posed by sacrifice.
\end{abstract}

\section{Keywords}

animal release - ethics - mythopoetic - paradox - sacrifice - scapegoat - Mongolia Southwest China

Sacrifice is always something of a paradox in that it has more than one ethical underpinning to it and yet tends to prioritise human well-being and the imperative to live. This ethical tension shapes the ways in which any given sacrifice 
comes to be conceptualised and practised. In this article, I propose that persons and animals routinely negotiate this tension during sacrifice and what I suggest is the related practice of animal release. To this end, I offer comparative ethnography on human-animal relations, mythopoesis, and the ethical motivations of sacrifice, animal release, and what I call contingent forms of slaughter among Buryats in northeast Mongolia and the Nuosu of southwest China. Each act of violence towards animals that I discuss here resonates with the form of cosmological exchange between persons and Buddhist or Daoist deities that is often called animal release. However, my ethnography diverges from the ways in which animal release is commonly practised in various forms of Buddhism and Daoism, where human longevity occasionally also takes precedence over animal welfare and even making merit (cf. Shiu and Stokes 2008: 188-93).

Typically, animal release involves deliberately freeing an animal from labour or slaughter, in return for the merit that deities bestow upon the person who performs this altruistic act (Shiu and Stokes 2008: 186). Animal release, then, is often conceptualised and practised in accordance with various Buddhist or Daoist ethics of compassion, self-sacrifice and charity (Vermander et al. 2018: 158-60, see also 101) or with the purpose of paying off a ransom or debt (Tan 2016: 4, see also 9). Yet since the persons who undertake animal release commonly do so with the intention of accumulating merit or longevity from deities, or, alternatively, of redressing wrongs and appeasing spirits (Law 1994: $336)$, they mobilise exchanges that are ultimately to some degree self-serving. Seen in this light, animal release is not a purely altruistic mode of sacrifice, but a means of improving a human life by freeing an animal one.

The ethnographic cases that I present in this article offer up a similar paradox, in which an animal is freed in exchange for the protection of specific persons, their households, and in some cases an entire village too-but with the added twist that this 'release' of an animal is approached as an apparent sacrifice and with a restraint on violence, which in some cases culminates in the slaughter of the animal. At first glance, my cases may appear to contravene the conventional understanding of animal release. However, my choice to invoke the term 'animal release' is based not only on how my Buryat and Nuosu fieldwork partners conceptualise and undertake the rituals that I discuss, but on the paradoxes that accompany the tensions that these rituals raise between more than one sacrificial ethos. In unpacking these paradoxes, I set out to offer a more expansive heuristic of animal release than has thus far been recognised within and beyond Inner Asia.

Before I can show what Buryat and Nuosu sacrifice or animal release involves and what these practices are intended to do, I need just briefly to provide some background to their religious and everyday life, including their human-animal 
relations. The Buryats are a Mongolian ethnic minority group, who are both shamanic and Buddhist (as followers of the Gelugpa and Nyingmapa traditions) and reside across the borderlands of Russia, Mongolia and China. In contrast, the Nuosu are a Tibeto-Burman group, also known by their Chinese ethnonym of 'Yi', who inhabit an animistic world (with some Daoist elements) that is ritually managed by priests and shamans. Each of these groups has a complex religious life underpinned by multiple and diverse ethics that feed into the paradoxes of their respective forms of sacrifice. While rural Nuosu reside in the Liangshan [Cool Mountain] forested highlands of Yunnan and Sichuan provinces in China, rural Buryats live in rolling hillside pastures or, occasionally, drier steppelands. There is some overlap in the animals that these two groups rear. Buryats keep cattle, sheep, goats and horses, while the occasional household may own a camel to transport caravans, raise a few pigs for meat (a practice associated with Chinese influence), or keep geese or chickens for their eggs (in what is considered to be a Russian-inspired practice). A wider variety of animals can be found among Nuosu households, which often keep chickens, pigs, sheep and goats, as well as the occasional horse for riding, mule for transporting goods, and cow, water buffalo, or yak to pull ploughs and provide meat. Unlike the Buryats, Nuosu do not have a tradition of collecting dairy products. Dogs are kept by both groups to guard homes, whereas cats are more or less tolerated.

Some agriculture lies at the heart of Buryat and Nuosu social life. Buryats keep vegetable gardens that in some years expand into small agricultural plots of chiefly carrots, spring onions, potatoes, cabbages, swede and turnips, while Nuosu are swidden agriculturalists who grow bitter buckwheat, maize, potatoes, highland rice, wheat (at altitudes that can tolerate it), white cloud beans, squash, chilli peppers, cabbage, daikon, swede, turnips, apples, walnuts, garlic and even cash-cropped pine trees or Chinese medicinal plants. Human-animal relations are key to the subsistence of each of these groups, who routinely accompany their animals out to pasture. Usually men shepherd sheep and goats, with Buryats often corralling them on horseback (or motorcycle) and Nuosu guiding livestock on foot due to their highland terrain. Much like Buryat women who get to know their cattle well by milking them, Nuosu women get to know their pigs well by cooking and feeding them daily meals of home-grown vegetables. But while Buryats and Nuosu excel at recognising the animals that they rear, both groups relinquish the relations they establish with their animals when it is time to consume them in the course of everyday life.

Hunting is another important arena of human-animal relations among Buryats and Nuosu. Not only does hunting add to their diets; it is the source of coveted talismans imbued with the power of spirits that reside in the wilderness and beyond human habitation. Both Buryats and Nuosu follow the 
common Inner Asian practice of hunting bear for their claws, which are kept by religious specialists and laypersons alike to ward off unwanted forces and spirit attacks. Buryats hunt wild boars, marmot and antelope for their meat, while harvesting the blood of antelope horns for its medicinal properties, whereas Nuosu hunt various wild birds (and notably pheasants) for their meat or to keep caged within their household courtyards for their eggs. Nuosu also revel in stories about the wild leopards they hunted in the past, which are now by all appearances extinct in their highlands, the pelts of which were kept by their nobility. Skins, horns, and sometimes the feathers and talons of wild animals are still kept in the homes of Buryats and Nuosu as symbols of status, hunting prowess and a connection to the powers of mountain spirits and other spirits of the landscape.

Now let me turn to my ethnographies of Buryat and Nuosu sacrifice, slaughter and animal release, which, as I suggest, are underpinned by more than one ethos. I start by discussing the conventional Buryat approach to slaughter before moving to my case study of a shamanic rite that involves releasing an animal in exchange for the protection of a human life. I then offer some general reflections on Nuosu slaughter with a discussion of three different animistic rites that involve releasing animals, but which ultimately culminate in what I call deferred sacrifice or contingent slaughter. Throughout this article, I use my ethnographic cases to illustrate that the mythopoetic contours of animal sentience and the human imperative to live are foundational to Buryat and Nuosu violence against animals or, alternatively, their decisions to free them. Finally, I conclude by reflecting on the paradox that any given sacrifice has multiple and competing ethical foundations to it.

Buryats sacrifice animals according to Mongolian conventions for slaughter. Sheep are the typical sacrificial animal, but occasionally goats, cattle, or horses are sacrificed too. Once an animal is chosen for sacrifice, it is brought to the site where the slaughter takes place. If it is a sheep or goat, then its smaller size will allow (usually) two men to undertake the sacrifice. While Buryat women do not slaughter animals, they frequently witness the act of sacrifice during shamanic ceremonies, where the animal is turned on its back for the kill. One man holds the animal's front legs alongside of its head, while smothering its muzzle with his free hand. A second man pulls the animal's hind legs towards himself, to ensure its belly is taut, before inserting a knife above the sternum with his free hand and drawing it downward to produce a long incision. Reaching into 
the body cavity, this second man snaps the aorta to still the heart. If he has not already pressed one of his shod feet against the animal's rump, then he will do this and hold it there for some moments after its death, as it is important that no bodily fluids are lost so that the 'whole' animal is sacrificed. To Buryats (and Mongols more generally), this mode of killing ensures the swiftest, least painful and most respectful death for an animal — while preventing any spilt blood (see also Fijn 2011: 226).

The reasons for sacrificing an animal in a shamanic ceremony are straightforward in Buryat terms. Shamans routinely harness the support and strength (chadal) of their shamanic spirits (ongod) in ceremonies that are held to address everyday problems, such as illnesses, accidents, business difficulties, or family discord. Buryats often also summon their shamanic spirits to improve the prospects of important undertakings, and especially those that involve travelling away from home for an extended length of time. While many ceremonies involve sacrificing an animal's life in exchange for the spirits' help in resolving problems, shamans frequently conduct smaller ceremonies and blessings that do not involve sacrifice. In the Buryat-majority regions of northeast Mongolia, and in particular the district of Bayandun in Dornod province with which I am most familiar, some persons are even dual practitioners of the shaman's and Buddhist lama's crafts (Swancutt 2012: 35). These dual practitioners hold sacrifices that are deemed appropriate in shamanic terms, even if this means going against the grain of certain Buddhist injunctions-and especially those of the Gelugpa or 'Yellow Hat' school—against killing animals. There is, moreover, a Buddhist monastery at the outskirts of Bayandun that houses lamas of the Nyingmapa or 'Red Hat' order, who set themselves apart from the local shamans by not conducting animal sacrifices. Yet many laypersons are happy to invite either a shaman or a lama to hold rituals for them. Moreover, the shamans, laypersons and even some of the local lamas seek to visit the central Gelugpa Buddhist monastery in the capital city of Ulaanbaatar on their occasional trips there. Thus, the ethics and intentions that underpin Buryat shamanic and Buddhist rites are sometimes blurred.

Central to my argument, though, is the shamanic ceremony that features the freeing of a live animal and resonates in some ways with the wider Mongolian herding practice of an animal release (seterlekh) ceremony. In this herding practice, an animal (typically an adult male) is selected from the herd, consecrated and thereafter allowed to live out its natural life freely without being killed for food (cf. Fijn 2011: 230-34). Fijn and White observe (this volume) that an animal may initially be designated for consecration by its distinctive markings and colouration. The chosen animal is often marked out visually from non-consecrated herd animals by tying a silk scarf around its 
neck or into its mane. Each consecrated animal provides protection for the herd, the surrounding area and, in some cases, a specific person who has been ill or is faced with an important concern. Much like the seterlekh ceremony, the particular Buryat shamanic ceremony that I discuss here has several ethical underpinnings to it. As I observed several times during my first fieldwork (in 1999-200o) in Bayandun, this ceremony involves freeing a live goat, sheep, or horse in order to protect a specific person, his or her household, and the places where the protected person may travel. While this ceremony is unusual, it is well established within the wider Buryat shamanic repertoire and involves summoning not only shamanic spirits, but the Buddhist spirit of the waters (lus), to whom effigies are burnt in lieu of a blood sacrifice. Burning effigies is a way of transferring them to the watery underground kingdom of the Buddhist spirit of the waters, which Buryats conceptualise as being filled with 81 water animals and 81 trees (cf. Swancutt 2012: 93-5).

I was present at several of these ceremonies conducted in 2000 by the local shaman I call Yaruu, who was my fieldwork host and shared a two-wing home with her mother, who I call Ölzii, at the time. Both of these women were making preparations for the shamanic levelling-up ceremonies (chanar) that Yaruu would soon conduct for another Buryat household of shamanic initiates from Aga Buryatia, Russia. As this household was overdue to arrive for an extended stay in Yaruu's home, Ölzii made a trip to visit them in Russia and check that everything was in order. This was at a time when soldiers were being recruited for the Second Chechen War (1999-2009), where heavy casualties and mortality levels were known to have decimated the Russian regiments. As Ölzii learned, the 21-year-old son of this Buryat household in Russia recently had been drafted into the war and his family were concerned for his safety. Ölzii therefore agreed that Yaruu could hold a shamanic ceremony involving animal release to protect him and, gathering up the necessary items for it, returned with them to her own home in Mongolia. A great deal of hope was vested in protecting this soldier by his family in Russia.

Since this particular ritual would culminate with the freeing of a goat that was meant to escape from Bayandun's district centre and head towards the surrounding hills, it was held in Ölzii's wing of the home. Although the entire household compound was imbued with a sense of shamanic protection, a palpable concern for the soldier hung over the ceremony. Large amounts of hay had been collected to produce a 'grass person' (övsön khün) effigy of the drafted soldier that was life-sized. The effigy was dressed in a full set of the soldier's clothes, including an army jacket, polyester trousers, socks, sneakers, thick mittens and a winter beanie ski cap. Because the soldier was not physically present, his photograph and a drawing based on it had been incorporated into 
the ritual as a way of incorporating his presence further into the ceremony. Attached to the head of the soldier's effigy was the drawing of his face, which had been rendered on a piece of white cotton. A thick rope made of twisted black and white wool also was tied around the effigy's neck at one end and loosely looped at its other end around the soldier's photograph. Yaruu confirmed that the rope would be cut during the ceremony to break the link between the soldier and the effigy, which would then be burnt outdoors in order to send it to the underground kingdom of the Buddhist spirit of the waters. Finally, a live goat would be released so that it would become the substitute target of any violence directed against the soldier in battle. As Yaruu observed, her shamanic spirits would protect the soldier by ensuring that gunfire, munitions, shrapnel, or other sources of harm would divert their course from the soldier and chase after the direction in which the released goat would run.

Laid out on Yaruu's offering table were cups of tea, milk, butter, meat and sweets, which would be given to both her shamanic spirits and the Buddhist spirit of the waters in lieu of a blood sacrifice. Summoning her spirits together with her shaman-in-training, who I call Duulchin, Yaruu adopted the perspective of Manjilai, a senior spirit and head of the Buryat shamanic levelling-up ceremonies. Speaking as Manjilai, Yaruu demanded the goat gruffly for upwards of 10 minutes as it was fetched by her husband and a friend from the nearby countryside, brought into Ölzii's home, wrapped in burlap to keep it prone, and laid on the floor while a horse bridle that had been modified into a leather harness was slipped over its muzzle. There were no distinctive markings to this all-white goat, which moments later was taken outdoors and released into the western hills surrounding Bayandun, as the soldier's effigy was burnt in Ölzii's courtyard.

Struck by the apparent similarities to the seterlekh animal release ceremony, I asked Yaruu if she had performed a variation on it. But she replied that the goat was not consecrated as a sacred animal in the usual manner, which tends to be done in daylight hours without any shamanic ceremony. When I asked if anyone might try to find, recognise or recapture the goat later, Yaruu confirmed that no such efforts would be made. She added that conducting the ceremony at night had helped to cloak the goat's departure and its direction of travel in the dark. Crucially for my argument, the goat had not been reared by the Buryats in Russia for whom the ceremony was held, nor did anyone in Yaruu's or Ölzii's household claim to have owned it. Thus, Yaruu observed that the goat was not expected to rejoin the herds of anyone involved in the shamanic ceremony, as would have been the case in a seterlekh animal release ceremony. As though to underscore this point, Yaruu approached me on the following evening and told me that, after holding the ceremony, she had dreamed that she 
had been seated next to the soldier's effigy. Giving me a significant look, she added that no one had found the released scapegoat. I asked if perhaps a local spirit (savdag) or ghost (chötgör) had taken it and she confirmed that this must have been the case, thereby hinting that the goat may have provided a kind of deferred sacrifice to the spirits. Just over a month later, Yaruu and Duulchin held this ceremony again for the soldier's mother, who by then had arrived in person with the shamanic initiates from Russia. A sheep procured locally for the occasion was released to protect the soldier's mother from the spirits that were trying to obstruct her shamanic levelling-up ceremony.

Folded into these two shamanic ceremonies were several distinct intentions, which, in mythopoetic fashion, evoked an ethos of animal release. There was the shamanic purpose of releasing a scapegoat to protect the soldier and his family against losing him in the first ceremony, followed by the sheep released to facilitate the shamanic skills of the soldier's mother in the second ceremony. Although different to a seterlekh animal release, each of these ceremonies shared the goal of protecting the person with an important concern wherever he or she happens to go. Yaruu's worship of the Buddhist spirit of the waters, to whom the effigies had been sent, furthermore was meant to harness this spirit's protection for the soldier and his mother.

Revealingly, each of Yaruu's ceremonies mythopoetically calls to mind the Buryat worship of certain Nyingmapa Buddhist deities that are held to keep animals, including goats, as their consecrated seter animals. Lars Højer (2019: 161) observes that several deities that are popular across Mongolia have goats as their seter animals, including 'Damdin's seter, Halhan Hairhan's seter, Üüriin Hairhan's seter or Jamsrai's seter'. Both Yaruu and the other shamans I knew in Bayandun often summoned one of these Buddhist deities - which are admired locally as powerful beings that ride upon their goat seter - to ceremonies that involved the sacrifice or live release of goats. Yet the two ceremonies that I have discussed here pivoted around the summoning of Manjilai, who is not associated with the Buddhist or white (tsagaan) side of Buryat shamanism. Manjilai is instead a spirit associated with the black (khar), or autochthonous, side of Buryat shamanic practices and is envisioned as riding bareback on one or sometimes two 'fallow' horses that (like Mongolian horses in general) are released to overwinter in the wild (Balogh 2011: 84-5, see also 210). Both of the ceremonies that Yaruu held also involved transferring grass person effigies to the Buddhist spirit of the waters and his kingdom that is replete with watery animals. Given this, the question arises: How might these mythopoetic referents be brought to bear upon the Buryat sacrificial ethos?

Consider how my Buryat cases evoke not only Maurice Bloch's (1992) concept of 'rebounding violence', but René Girard's observation that sacrifice is 
a response to an act of violence, which is only restrained by offloading the responsibility for that violence onto a scapegoat ([1997] 2005: 101-4). Here, the initial violent act would be the drafting of the soldier, which was restrained by ensuring that the goat became the target of enemy fire instead. But Girard takes this a step further by suggesting that 'myths are the retrospective transfiguration of sacrificial crises' (2005/1977: 67). I take Girard here to mean that myths open up a social space for persons to interpret and give expression to the (ethical) crisis that underpins any given sacrifice, where violence must be broached with some degree of restraint. My argument rests upon a similar premise, but I suggest that every sacrificial ethos is already founded upon a diverse set of ethical and mythopoetically inflected intentions, such as those that underpin shamanic blood sacrifice and a Buddhist-inspired bloodless approach to sacrifice. In Yaruu's two ceremonies that I have described above, mythopoetic connections can be drawn to Buddhist deities that keep seter animals and are associated with both the sacrifice and release of animals. But the key connections are to Manjilai, who appeared at these ceremonies as a spirit who periodically releases his mounts into the wilderness, and the Buddhist spirit of the waters that requires effigies in place of blood sacrifices. Perhaps it is not surprising, then, that the tensions underpinning the sacrificial ethos in Yaruu's ceremonies reached an 'anti-sacrificial' denouement, sensu Girard (1978: 180), when she attributed the disappearance of the scapegoat (and later, the sheep) not to human violence, but to the spirits and - paradoxically - to these animals' own agency in running away too. As I will now show, the penchant for offloading violence in a roundabout way onto an animal also pervades Nuosu animistic rituals, which prioritise the human imperative to live by drawing upon some rather different ethical and mythopoetic wellsprings.

Nearly every Nuosu ritual conducted by a priest (bi mox $k \bar{\kappa}$ ), male shaman (su nyit 片当), or female shaman (mop nyit $\curvearrowright *$ ) involves animal sacrifice. There are, however, different methods of sacrifice for different animals and ritual occasions. Nuosu usually slaughter animals by slitting or gouging their throats, except in the case of goats, which are less auspicious and thus need to be smothered during a sacrifice. Another exception is the drowning of a chicken as the household's first sacrifice for the Torch Festival. Each sacrificial animal is offered to the ancestral and animistic spirits before people consume its meat. Yet Nuosu occasionally approach sacrifices or slaughters in ways that defer an animal's or make it contingent upon their ritual processes. 
There are distinctly paradoxical underpinnings to what I call deferred sacrifice and contingent slaughter, which prioritise the human imperative to live. Nuosu are aware that some of their neighbouring ethnic groups practise animal release as a merit-attracting act with various Buddhist or Daoist permutations to it, but they contrast this to their own forms of sacrifice and slaughter. They emphasise that in nearly every case where they appear to release an animal from death, the animal actually receives only a temporary reprieve and eventually dies. As Nuosu point out, different intentions are ascribed to their deferred sacrifices and contingent modes of slaughter, each of which illustrates a rather different conceptualisation of 'animal release'. More than one ethic is thus paired up in the practices that I discuss here, calling to mind the rebounding violence theme in Girard ([1997] 2005) and Bloch (1992).

Let me start with the Nuosu ritual for deferring a sacrifice, which like the Mongolian consecration of animals starts off by marking the chosen animal with a sign that makes it visibly identifiable. ${ }^{1}$ Nuosu produce these signs by cutting one ear of the chosen ox, sheep, goat, or pig, which is left with a permanent scar or slit. Alternatively, they pierce the fleshy part of the cockerel's scalp, just below the base of its cockscomb, with a needle in order to loop a length of red thread through it that counts as its sign. The choice to defer a sacrifice extends the chosen animal's lifetime, but it does not confer an indefinite lease on life. Instead, the animal is slaughtered after a year, or in some cases, after three years. I learned about this form of deferred sacrifice in summer 2019, when travelling with an all-Nuosu research team comprised of the anthropologist I call Tuosat, the ethnologist I call Mitsu and the priest I call Obbu, from Yunnan to Sichuan province, where we met with other priests to exchange knowledge about unusual rituals. We discussed how Nuosu adopt the practice of deferred sacrifice when faced with a series of natural disasters, such as droughts, heavy rain, mudslides, or earthquakes, which are attributed to the wrath of the local mountain spirit ( $m u$ si H $\mathrm{H}$ ). There is a great deal of local lore about mountain spirits in Nuosu areas, which, as the owners of wild animals, are known to cause illness and natural disasters when angered by persons who hunt without their permission (cf. Bender \& Aku 2019: lxxxiv). Some mountain spirits become wrathful when their trees or other resources are harvested wantonly. Angry mountain spirits may retaliate by imparting illness and madness upon

1 Nuosu refer to their practice of deferred sacrifice with a turn of phrase that first names the sacrificial animal and then adds the verb 'to put a sign on' (yip dit $\mathbb{X}_{\mathbb{N}\}}$ ). They therefore call

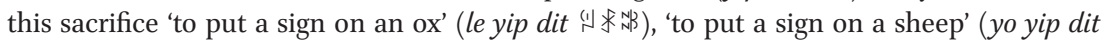

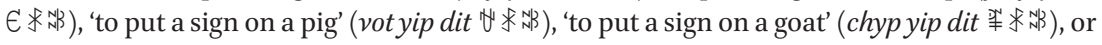
'to put a sign on a chicken' (va yip dit $\aleph^{*} \mathbb{N}_{\mathrm{N}}$ ). 
specific persons and capturing their souls; it is also possible that a mountain spirit will choose to retaliate against the persons who live within its area by causing natural disasters.

To avert future disasters, a household or entire village may decide to put a sign on an animal and raise it for a set length of time, during which they defer its ritual slaughter and their feasting on it until the appointed moment when they sacrifice it to the mountain spirit. Households use divination to gauge whether they should raise a sheep, pig, goat, or chicken for a year before slaughtering it, basing their selection on which animal tallies best with the astrology of the household head. When an entire village comes together collectively to raise an ox for three years, though, they dispense with the divinatory selection of the animal and rotate the sacrificial ox between households so as to spread out the burden of feeding and caring for it. Eventually, the chosen animal is slaughtered by a priest, who sacrifices it to the local mountain spirit in order to stave off natural disasters in future. Another young animal is selected to be raised in its place, thus setting in motion a cycle of deferred ritual slaughters. As Obbu explained, every animal selected for a deferred sacrifice must be male and whole (i.e. uncastrated), except for pigs, which must be castrated. Tuosat added that although the animal eventually dies, its death is delayed by the guaranteed wait time for its slaughter, which other animals do not have. The intention behind deferring the chosen animal's death is not only to fatten it up for the feast, but to show restraint in killing and eating it on behalf of the mountain spirit. Deferred sacrifices are thus paradoxically underpinned by the Nuosu ethic of animal release and their ethic of sacrifice, the combination of which leads to an initial withholding of violence but concludes with an animal slaughter.

Observe how the paradox is taken further in contingent forms of slaughter that are held to deflect certain dangerous beings, such as the lightning spirits. In Nuosu aetiology, persons contract rheumatism through exposure to the radiation (cut jyp struck by lightning in order to be harmed by it. Nuosu commonly give the example of the person who sits beneath a tree that had been struck by lightning and unwittingly absorbs second-hand radiation from the tree that leads to rheumatism. Other forms of radiation, such as ultraviolet rays, are sometimes also sourced to the lightning spirits. Much like local mountain spirits, lightning spirits stand in a hierarchically senior and potentially dangerous relationship to human beings. Unique to the lightning spirits, though, is their extreme attraction to blood, which becomes pronounced in a ritual context where they are prone to strike suddenly or send their radiation at speed. Thus, the ritual for rheumatism (sy six bi Y $\mathrm{Y} / \mathrm{K}$ ) is meant to be devoid of blood sacrifice, although 
some priests choose to slaughter frogs or toads when a patient's symptoms remain severe despite the effort to heal them.

As Mitsu and Obbu explained, rheumatism may be caused by radiation, but it is also attracted to damp places. Rheumatic persons often feel pain in their joints when it is damp and may acquire dermatitis, which causes their skin to resemble the bumpy and mottled appearance of frogs or toads that seek out damp places to live. Thus, when conducting the ritual for rheumatism, Obbu may address the radiation, joint and skin problems collectively. He starts by preparing the key items on a mountaintop where the ritual must be held. Since lightning is attracted to brass or copper, he puts a brass cap that is bowl-shaped on the head of the black male goat chosen for the ritual. Obbu then draws a lightning spirit on a long flat wooden ghost board, which is its effigy. Beneath his image of the lightning, he draws the image of the culture hero Zhyge Alu, who is credited with having tamed lightning, having reduced insects, frogs, and snakes to their current size, and for having shot down the excess suns and moons that scorched the earth in Nuosu myth history (cf. Bender 2008: 16). He also draws a cockerel and a goat and writes beneath them some Nuosu priestly scripture for expelling lightning. Both the wooden ghost board and some bamboo stakes are planted in the ground, to indicate the many roads along which the lightning will be made to ritually travel. At the culmination of the ritual, Obbu bundles up the lightning's effigy with the bamboo stakes, binds them to the back of the goat, and then releases it into the wilderness of the mountaintop. The intention here is to equip the goat with items that attract the lightning spirits, namely: an item of brass and the lightning's own effigy. This way, the lightning spirits will chase after the goat once it is released, rather than attacking the rheumatic patient. Just as in the Buryat shamanic ceremony discussed above, no effort is made to find or reclaim the goat afterwards.

Many priests make no further use of animals in the ritual for rheumatism, but Obbu conducts one further ritual step for his patients who have acquired dermatitis. To this end, he requests that one or more live frogs or toads are caught in advance by the household that invites him to conduct the ritual. Nuosu do not distinguish frogs from toads, both of which are called by the

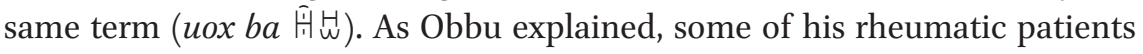
have even shared their tips on where frogs or toads can be captured in winter ponds that do not fully freeze, so that he can make use of this technique at all seasons. Once equipped with a box of frogs or toads for the ritual, Obbu carries them to one of the natural streams that crisscross the Nuosu highlands, or to some other damp place on the mountaintop. Here, he prepares to send the rheumatism to its natural damp habitat. After heating a few stones in an impromptu fire, he fumigates his patient with steaming herbs while reciting 
priestly chants. If the patient's symptoms appear to clear after this first fumigation, Obbu will release the toads or frogs, allowing them to leap off into the damp area, carrying the rheumatism away with them. But if the patient's symptoms remain severe, Obbu may choose to kill the toads or frogs by striking them hard with his hand. He then carefully skins the frogs or toads and applies their flesh to the painful joints or itching skin of the patient. These applications of toad or frog skin are meant to absorb the rheumatic pain and dermatitis from the patient, just as the patient had initially absorbed the radiation of lightning. Having allowed the toad or frog skin applications to do their work for some minutes, Obbu transfers them to the heated stones so that they may join the herbs used for fumigating the patient, who further absorbs their benefits in vaporous form.

Allow me to pick up the discussion of mythopoetics again here, as this feeds into the ethical paradox that underpins this particular sacrifice. I have just discussed how Obbu uses herbal fumigation to clear a patient's rheumatic dermatitis. It is only when the herbs alone do not work that he must kill the frogs or toads to fumigate a patient with their skin, making this act of violence contingent on the patient's symptoms. Now there is a sense in which this violence is surprising. Nuosu have a taboo against killing or eating frogs or toads, which is often traced to their 'Book of Origins' (Hnewo Tepyy 新手术 d), an oral history of creation tales. Frogs appear in this oral history as one of the 'six animals with blood' that originated in ancient times and hold a kin relationship to human beings (Bender 2008: 16-17; Bender \& Aku 2019: 36). Like people, frogs also have five digits on each hand and foot, which gives them a human-like appearance and renders them inedible. Beyond this, there are numerous Nuosu myths in which the clever frog saves humans or joins forces with them for their mutual benefit (see Bender 2008: 20-21, 31-32). These myths show that the frog occasionally seeks to mutually benefit from its relationship to humankind so that both can pursue the imperative to live their lives to the fullest. Tellingly, the frog's mythic service to humans does not lead to its death-although it does make the frog lose its human-like capacity for speech.

Tuosat shared with me the version of the myth that he knew best about the frog's service to humankind some weeks ahead of our shared research trip in summer 2019. He started with the race that the sky spirit Ngetit Guxnzy ordained would take place so that all of the world's animals could compete for the ability to speak (cf. Bender \& Aku 2019: $38-9$ ). As Tuosat explained, all creatures could speak in ancient times. However, the cacophony was too much for Ngetit Guxnzy to bear, so he chose to eliminate the speech capacity of most animals by allowing only the winner of the race to claim it as a prize. During the race, the human and the frog fell far behind their faster 
competitors, who appeared to be the likely winners. But as the frog hopped alongside the human, it spoke to him, requesting that it might ride on the human's shoulder to cross the finish line faster. In exchange, the frog promised to tell the human how to identify the waters of wisdom that they would need to drink at the end of the race in order to retain the capacity for speech. It turned out that Ngetit Guxnzy had added an extra obstacle to the race by arranging that both the waters of wisdom and the waters of dullness would be available at the finish line. The frog said that it could share the secret of which waters to drink. Agreeing, the human put the frog on his shoulder and, while racing along, heard it whisper that the waters of wisdom were not pristine, but had a clouded, dirty, and unpalatable appearance. Each of the fast-racing animals that beat them to the finish chose the more attractive looking waters of dullness and eliminated themselves from the competition. Thus, when the human and frog finally arrived, the waters of wisdom were still available for them to claim. By that point, though, the human was overcome by a burning desire to slake his thirst. Grabbing the waters of wisdom that the frog had told him were hidden within the petals of an azalea flower, the human forgot to share and greedily gulped down all but the last drop, which the frog, who feebly protested on the side, had to be content to drink. This is why the frog can only croak and no longer communicates with the full speech capacity that it helped to bestow upon humankind.

Note that the outcome of this race depends upon the frog's service to humankind, just as the priest's decision to release or kill the frogs and toads in the ritual for rheumatism depends upon his initial success in fumigating a patient. The mythopoetic link between frogs and the humans who may unpredictably swallow up their help is important here. Like the deferred sacrifices to mountain spirits that Nuosu hold to avoid natural disasters, the handling of the frog or toad starts off with a restraint on violence, which, however, is lifted when its slaughter can no longer be avoided. Both an ethic of contingent violence and an ethic of animal release, then, ultimately underpin the ritual for rheumatism. It is the paradox of drawing upon each of these ethics, and their mythopoetic referents, which ensures the human imperative to live.

One last example of contingent slaughter will suffice to underscore my argument. Much like the ritual for rheumatism, Nuosu have a ritual for tuberculosis (nyut na rep na $\Theta$ 抱), which is conceptualised as 'the prolonged illness of the monkey' and resonates mythopoetically with that animal. The ritual for tuberculosis involves an exceptionally expensive sacrifice that is meant to have an assured result, and yet unfolds with its own particular contingency. Obbu conducted this ritual over the course of 10 days in February 2019, which required that his ritual host sacrifice sheep, pigs, chickens and goats to the total 
order of 90,000-100,000 Chinese yuan. ${ }^{2}$ But the ritual also involves capturing a live monkey, which is usually the golden snub-nosed monkey (Rhinopithecus roxellana), from the forested mountains that Nuosu inhabit. As Obbu explained, during the climax of this ritual, he ensures that the tuberculosis is ritually absorbed by the monkey and all of the ritual effigies that he produces, which are securely enclosed together inside a specially prepared goatskin or cowhide bag. ${ }^{3}$ Divination is then used to decide on one of three methods for abandoning the monkey in this bag: leaving it in a treetop in the forest, putting it in a river, or interring it in a deep natural hole in the ground that the priest covers with a large and heavy stone. These methods ensure that the tuberculosis is captured and expunged from the area. Yet Obbu admitted that each method for abandoning the money cannot help but eventually lead to its death, as he assumed happened not long after he divined that the monkey in the ritual that he held in 2019 should be abandoned in a deep natural hole sealed with a stone cover. However, Obbu was careful to stress - and the rest of Tuosat's research team agreed-that Nuosu conceptualise this abandonment as a contingent form of slaughter. It is only after the monkey is abandoned that it suffocates. No one sets out to asphyxiate the monkey, which is sent away in order to ensure the patient's imperative to live.

Abandoning the monkey is a complicated choice for Nuosu because of its relationship to human beings. Like frogs and humans, monkeys are one of the six animals with blood in the Book of Origins (Bender 2008: 16). Monkeys also have five digits on each hand and foot, making it taboo for Nuosu to kill or eat them. Nonetheless, monkeys hold an ambivalent place in Nuosu cosmology that is traceable to the Book of Origins, where the Spirit Monkey takes a lead role in the production of the cosmos and in its undoing. It is the Spirit Monkey who hammers the excess suns and moons out of gold and silver and positions them within the skies, causing the earth to overheat and then exacerbating the situation by clumsily sacrificing a chicken (Bender 2008: 30; Bender \& Aku 2019: lxviii, see also 18-20). Recall that it was the culture hero, Zhyge Alu, who shot down these excess suns and moons while taming lightning and downsizing frogs, snakes and insects. Thus, the priest's abandonment of a monkey during the ritual for tuberculosis resonates directly with Zhyge Alu's mythopoetic act of taming the Spirit Monkey's dangerous excesses. Nuosu priests who abandon monkeys, then, pair this contingent form of slaughter with their ethic

2 This was equivalent at the time to £10,260-£11,400 in British pounds.

3 Care is taken when producing these bags to avoid skinning the goat or cow by cutting it down the middle, as only an unbroken bag is suitable for containing tuberculosis. To peel off the hide in a single piece, Nuosu make precise incisions around each ankle and the neck. 
of animal release-while openly admitting the tensions between them-to secure their patient's imperative to live.

\section{Concluding Reflections on Paradox and the Ethical Tensions in Sacrifice}

In studies of sacrifice, the ethical tension between the pursuit and restraint of violence is often overshadowed by the focus on death. Yet as the raison d'être for sacrifice is typically the human imperative to live, it makes good sense to focus upon the mix of conflicting motivations that underlie acts of ritual violence. Throughout this article, I have suggested that the multiple ethical underpinnings to certain Buryat and Nuosu modes of sacrifice, contingent slaughter or animal release invite us to consider how violence offloaded onto animals echoes the mythopoetic relationships that persons hold to them. I have proposed this line of argument because sacrifice and other forms of ritual violence frequently resonate with myths and legends that reveal and shape human-animal relations (cf. Law 1994: 327-28, see also 337-42). The mythopoetics of human-animal relations even frequently shed light on why persons perform acts of ritual violence on animals in the specific ways that they do.

By offering ethnography that echoes (even as it diverges from) the typical forms of animal release in Inner Asia and elsewhere, I have highlighted one of its signature characteristics: the restraint on violence. Animal release may be undertaken with the intention of attracting merit from various Buddhist and Daoist deities, but the choice to release an animal from slaughter or work goes beyond the rewards of merit-making (Shiu and Stokes 2008: 194). My Buryat and Nuosu studies in this article show that certain forms of animal release (and their mythopoetic exemplars) are meant to contain the violence meted out in sacrifice. The restraint on violence is thus a key feature not only of the consecration of sacred animals in the Mongolian seterlekh ceremony, but of the Buryat shaman's release of scapegoats and Nuosu priestly approaches to deferred sacrifice and contingent slaughter.

Yet while the withholding of violence is vital to sacrifice contingent slaughter and animal release alike, it is also the source of paradox within them. So long as sacrifice, slaughter, or the freeing of animals contain both the release from and dogged pursuit of violence, which leads to rebounding violence ( $\grave{a}$ la Bloch 1992) and the acts of counter-violence (sensu Girard [1997] 2005) that sustain them, they will unfold according to their own conflicting ethical foundations. Perhaps no one can fully resolve this ethical tension, but there is scope for harnessing it to protect the human imperative to live. By creatively drawing 
upon the mythopoetic resonances between the mutually beneficial features of human-animal relations and acts of violence, Buryats and Nuosu settle upon their particular ethic of choice. What better way could there be to move beyond paradox?

\section{Acknowledgements}

I would like to thank the editors for their invitation to join this special issue and the three anonymous reviewers at Inner Asia for their stimulating comments on an earlier version of my article. Thanks go to Kate Crosby too for her generous and timely comments, which I have endeavoured to address with limited space. Any shortcomings in this work are, of course, mine alone.

\section{References}

Balogh, M. 2011. Contemporary Buriad Shamanism in Mongolia. Unpublished PhD dissertation, Eötvös Loránd University. (accessed 29 May 2020) http://doktori.btk.elte .hu/lingv/baloghmatyas/diss.pdf.

Bender, M. 2008. 'Tribes of Snow': animals and plants in the Nuosu Book of Origins. Asian Ethnology 67(1): 5-42.

Bender, M. \& W. Aku. 2019. The Nuosu Book of Origins: A creation epic from southwest China. Seattle (WA): University of Washington Press.

Bloch, M. 1992. Prey into Hunter: The politics of religious experience. Cambridge: Cambridge University Press.

Fijn, N. 2011. Living with Herds: Human-animal coexistence in Mongolia. Cambridge: Cambridge University Press.

Girard, R. 1978. Things Hidden since the Foundation of the World (trans. S. Bann \& M. Metteer). Stanford (CA): Stanford University Press.

Girard, R. [1997] 2005. Violence and the Sacred (trans. P. Gregory). London/New York: Continuum.

Højer, L. 2019. The Anti-Social Contract: Injurious talk and dangerous exchanges in northern Mongolia. New York/Oxford: Berghahn.

Law, J.M. 1994. Violence, Ritual Reenactment, and Ideology: The 'Hōjō-e' (Rite for Release of Sentient Beings) of the USA Hachiman Shrine in Japan. History of Religions. 33(4): 325-57.

Shiu, H. and Stokes, L. 2008. Buddhist animal release practices: historic, environmental, public health and economic concerns. Contemporary Buddhism: An Interdisciplinary Journal. 9(2):181-96. 
Swancutt, K. 2012. Fortune and the Cursed:The sliding scale of time in Mongolian divination. New York/Oxford: Berghahn.

Tan, G.G. 2016. Life and 'freeing life' (tshe thar) among pastoralists of Kham: intersecting religion and environment. Études Mongoles et Sibériennes, Centrasiatiques et Tibétaines 47: 1-15.

Vermander, B., L. Hingley \& L. Zhang. 2018. Shanghai Sacred: The religious landscape of a global city. Seattle (WA): University of Washington Press. 